\title{
Agarwood Leaf Essential Oil Characterization and Effects on MCF-7 Breast Cancer Cells
}

\author{
Nur A. A. Zainurin ${ }^{1}$, Yumi Z. H-Y. Hashim² ${ }^{2}$ Nor F. Mohamed Azmin ${ }^{1}$, Phirdaous Abbas ${ }^{1}$ \\ ${ }^{l}$ Department of Biotechnology Engineering, Kulliyyah of Engineering, International Islamic University Malaysia (IIUM), Jalan Gombak, \\ 53100 Kuala Lumpur, Malaysia \\ E-mail: aimialiahz@gmail.com, norfadhillah@ilum.edu.my, phirdaous.abbas@gmail.com
}

\author{
${ }^{2}$ International Institute for Halal Research and Training (INHART), International Islamic University Malaysia (IIUM), Jalan Gombak, 53100 \\ Kuala Lumpur, Malaysia \\ Corresponding author e-mail: yumi@iium.edu.my
}

\begin{abstract}
Breast cancer continues to remain as the leading cause of cancer mortality among women worldwide. Agents for prevention and cure for breast cancer are contiuously being researched. In particular, agarwood essential oil from resin infiltrated heartwood has been reported to have substantial evidences of medicinal benefits. Nevertheless, there is very limited report on agarwood leaf essential oil (ALEO). Hence, this present study was conducted to evaluate the physicochemical properties, chemical constituents and anticancer activity of ALEO. ALEO was observed to be of pale-yellow colour with sweet smell. Other physicochemical properties include refractive index of 1.44 , specific gravity of 0.886 , saponification value of $131.88 \mathrm{mg} \mathrm{KOH} / \mathrm{g}$, acid value of $2.80 \mathrm{mg} \mathrm{KOH} / \mathrm{g}$ and iodine value of $105.07 \mathrm{gI} / 100 \mathrm{~g}$. The profiling of chemical constituents using gas chromatography-mass spectrometry (GCMS) revealed 19 compounds. Hexadecanoic acid was the major compound (64.41\%). The biomarkers of agarwood; azulene $(\mathbf{0 . 6 1 9 \%})$ and guaiol $(\mathbf{0 . 2 9 9 7 \% )}$ ) were also detected. ALEO was tested for anticancer activity against MCF-7 cancer cells using WST-8 assay. ALEO showed the $\mathrm{IC}_{50}$ value of $31 \%(\mathrm{v} / \mathrm{v})$ against MCF-7 cells after 36 hours of treatment. In conclusion, this study provides information on ALEO physicochemical properties and chemical constituents that can be used as benchmark for quality assurance as well as proof that ALEO holds a potential as anticancer agent.
\end{abstract}

Keywords - Agarwood leaf; breast cancer; essential oil; GCMS; MCF-7.

\section{INTRODUCTION}

Based on Global Cancer Statistics conducted by the International Agency for Research on Cancer (IARC), out of 8.2 million cancer-related deaths recorded in 2012, it was reported that more than 500,000 deaths were due to breast cancer [1], [2]. World Health Organization (2015) defined cancer as the rapid growth of abnormal cells (single cell that transforms from a normal cell into tumour cell) which have the tendency to develop and spread at any part of the body [3]. For many years, breast cancer has been listed as the top killer among women which accounted for $15 \%$ of all cancer deaths among females and $25 \%$ of the total cancer cases [1][3].

Breast cancer commonly occurs in the breast tissue with the major sign of the presence of lump in the breast. In addition, breast cancer begins in the cells from the lining of milk ducts and the lobules which are responsible to supply milk to the ducts. Ductal and lobular carcinoma refer to the cancers that develop from the ducts and lobules respectively [4]. The risk factors that may trigger breast cancer include hormonal and reproductive factors, overweight, physical activity and alcohol consumption [3], [4]. However, it was reported that the mortality from breast cancer is continuously reducing due to screening and early detection as well as the enhancement of the adjuvant therapy. Nevertheless, breast cancer continues to remain as the leading cause of cancer mortality for women whereby one in every eight women has the potential to be diagnosed with breast cancer in her lifetime [5], [6].

Despite the emergence of modern anticancer therapy, it is estimated that more than $60 \%$ of clinically approved anticancer drugs are derivatives of the medicinal plant due to its efficacy and safety as well as being eco-friendly and lowcost as compared to the conventional treatments methods [2]. Hence, natural compounds from plant species including from agarwood species have been continously being explored and 
investigated as the alternative for anticancer drugs. Agarwood which is also known as gaharu, Oudh, Jin-koh and chen-xiang, is treasured for its dark-aromatic resin which is formed either naturally or artificially in the heartwood of Aquilaria species [7], [8]. It is one of the most valuable woods in the world with high demand and price due to its myriad applications in three main areas: perfume, incense and medicine [7].

Interestingly, other than the prized fragrant wood, agarwood tree also offers many different types of raw material which can be exploited. In particular, agarwood leaves which generally have a length of 5 to $11 \mathrm{~cm}$ and diameter of 2 to $4 \mathrm{~cm}$ with an elliptical blades shape; have been commercialized into products such as agarwood tea and essential oils [9]. Recently, research focus has been shifted towards the agarwood leaf due to its wide range of functional groups with diverse chemical constituents which may correlated with their pharmacological activities [9]. Previous studies reported that agarwood essential oil from the resin infiltrated heartwood exhibited anticancer activity [10]-[12]. Nevertheless, study on agarwood leaf essential oil (ALEO) in terms of its quality assessment, chemical constituents and biological effects paticularly anticancer activity are limited. It is therefore, the interest of this study to investigate the potential anticancer effects of ALEO which may be positively associated with its physicochemical properties and chemical constituents.

\section{MATERIAL AND METHOD}

\section{A. Raw Material, Cell Line and Culture Medium}

$50 \mathrm{ml}$ of agarwood leaf essential oil (ALEO) was purchased from Best Formula Industries (EssentialOils.com.my). ALEO was extracted using cold press method as stated by the manufacturer. However, the species of agarwood used was not specified. Michigan Cancer Foundation (MCF-7) breast cancer cell line was purchased from ATCC. The cell line was cultured and maintained in Dulbecco's modification of Eagle's medium $(\mathrm{DMEM})$ with high glucose and L-glutamine (Gibcoß) and $10 \%(\mathrm{v} / \mathrm{v})$ fetal bovine serum (FBS) at $37^{\circ} \mathrm{C}$ and $5 \% \mathrm{CO}_{2}$.

\section{B. Experimental Methods}

1) Physicochemical Analysis: Several physicochemical properties of ALEO were investigated. The colour and clarity were visually observed while the characteristic odour was analysed by sniffing [13]. The refractive index of ALEO was determined by using ATAGO PAL- $\alpha(0-85 \%)$ handheld refractometers based on the manufacturer's instructions and the Brix values were converted to refractive index based on the International Scale (1936) of Refractive Indices of Sucrose Solutions at $20^{\circ} \mathrm{C}$ [14], [15]. The specific gravity of ALEO was measured by using DA-130N (Kyoto Electronics, Japan) portable density/specific gravity meter (densimeter) based on manufacturer's instructions. Saponification value was determined by standard procedure based on Paudyal et al. (2012) [16]. The acid value was determined based on Barkatullah et al. (2012) [17] and AOAC (2000) [18]. Subsequently, the iodine value was determined based on Paudyal et al. (2012) [16].
2) GCMS Profiling of ALEO Chemical Constituents: The volatile constituents of the triplicate ALEO samples were analysed by using gas chromatography system (GCMS); Agilent 7890A (Agilent Technologies) coupled with Agilent 5975C quadrupole mass spectrometer and autosampler. Hewlett Packard (HP-5MS) ultra inert silica capillary column (30 m x $0.25 \mathrm{~mm} ; 0.25 \mu \mathrm{m})$ was used. The analytical conditions for GCMS analysis were based on Hashim et al. (2014) [19]. The detected peaks and mass chromatograms were further used to identify total ion chromatography (TIC) in accordance to the National Institute of Standards and Technology (NIST) 2008 mass spectral library.

3) Investigation of ALEO In-Vitro Anticancer Activity: The procedure for this section was based on the protocol of WST-8 assay provided by Nacalai Tesque, Inc. [20]. Accutase was added to the culture flask to detach the confluent cells. Cell counting was performed in order to determine the seeding number for the 96-well tissue culture plate. The cell suspension with 5000 cells/well was prepared using the culture medium. $100 \mu \mathrm{l}$ of the cell suspension was added to each well of a 96-well plate. The medium was preincubated in $\mathrm{CO}_{2}$ incubator at $37^{\circ} \mathrm{C}$ for 24 hours. Then, $10 \mu \mathrm{l}$ of the ALEO prepared sample was added into each well of the plate. The medium was incubated for 48 hours at $37^{\circ} \mathrm{C}$ in $\mathrm{CO}_{2}$ incubator. Next, $10 \mu \mathrm{l}$ of WST- 8 reagent was added into each well. Then, the medium was incubated for 1 hour at $37^{\circ} \mathrm{C}$ in $\mathrm{CO}_{2}$ incubator. The experiments were conducted in triplicate and the measurement of the absorbance was conducted at $450 \mathrm{~nm}$ by the microplate reader. $\mathrm{IC}_{50}$ value was derived from curve-fitting methods. The percentage viability of the cells was calculated using formula below [21]:

$\begin{aligned} & \text { Percentage of cell } \\ & \text { viability }(\%)\end{aligned}=\frac{\text { Mean absorbance sample }}{\text { Mean absorbance control }} \times 100$ (1)

\section{RESULTS AND DISCUSSION}

\section{A. Physicochemical Analysis}

The commercial importance of oils generally depends on qualitative parameters such as physicochemical characteristics which give the baseline data to evaluate its suitability for consumption and use. The practical importance of the essential oil in daily life can be explored by studying various physicochemical properties of the oils. The common physicochemical properties of essential oil include organoleptic properties (colour and odour), refractive index, specific gravity, saponification value, acid value and iodine value. These properties are significantly influencing the quality of oil and therefore are normally used as quality control parameters [17].

From the physicochemical tests of this present study, ALEO had a pale-yellow colour with sweet strong smell. The refractive index of ALEO was 1.440 while its specific gravity was 0.886. Refractive index describes the propagation of light through a medium measured by a refractometer. It is also used to differentiate water from other solvents as well as to determine the purity level of the 
essential oil [22]. Generally, the value of refractive index is more than one for light passing from less dense medium (air) into a denser medium (oil) [23]. The presence of high amount of water content in oil results in small refractive index because light is easily refracted in water as compared to oil due to the difference in density of the liquids. Therefore, the essential oil with large refractive index has better purity and quality than the essential oil with small refractive index since it indicates less amount of water present in the essential oil. On the other hand, specific gravity of oil refers to the ratio of the weight of a given volume of the oil to the weight of an equal volume of water at room temperature. Specific gravity value of essential oil is usually less than one [17]. In comparison, the agarwood essential oil has higher specific gravity of 0.952 [24] as compared to ALEO (0.886). Technically, agarwood or the dark aromatic resin is formed within the heartwood of the agarwood species. Thus, the oil extracted from the heartwood is more concentrated and denser which results in a higher specific gravity as compared to the oil extracted from the leaves [7].

Saponification value of ALEO was $131.88 \mathrm{mg} \mathrm{KOH} / \mathrm{g}$. Saponification value is defined as the index of average molecular mass of the fatty acids in the essential oil. High saponification value indicates high molecular mass of fatty acids in the oil [17]. Based on GCMS analysis, there were seven fatty acids compounds identified which accounted for $69.64 \%$ of the total oil content. Thus, high percentage area showed that ALEO has high molecular weight of fatty acids that resulted in a high saponification value. Saponification value also suggests the suitability of the oil for soap production [17]. This is because soap is the potassium or sodium salts of fatty acids prepared by saponification process [25]. Hence, it suggests that ALEO can be potentially used for making soap.

Acid value is defined as the mass of potassium hydroxide in milligram which is required to neutralize one gram of chemical substance [22]. For this present study, the calculated acid value of ALEO was $2.805 \mathrm{mg} \mathrm{KOH} / \mathrm{g}$ which is within the limit since the maximum level of acid value of oil extracted from plant-based sources by cold pressed is 4.0 $\mathrm{mg} \mathrm{KOH} / \mathrm{g}$ [26]. The low amount of acid value indicates slower deterioration and rancidity of oil. Rancidity will cause oil to have foul smell while deterioration will lead to chemical degradation; affecting the stability and volatile property of the essential oil which will then lead to lower aromatic quality and therapeutic value of essential oil [27], [28].

Subsequently, iodine value measures the number of grams of iodine consumed by $100 \mathrm{~g}$ of oil or fat [25]. The measured iodine value of ALEO was $105.073 \mathrm{gI}_{2} / 100 \mathrm{~g}$. The oil with low iodine value is less likely to be oxidised [25]. Thus, it suggests that ALEO has high level of oxidative deterioration as compared to olive oil since the maximum level of iodine value of virgin olive oil is 75 to $94 \mathrm{gI}_{2} / 100 \mathrm{~g}$ [26]. Oxidation of the essential oil may disrupt chemical composition leading to loss of efficacy or it can become hazardous [29]. The measured physicochemical properties were compared with published results of olive oil (the most common base oils obtained from plant) and agarwood oil from infiltrated heartwood [24], [26], [30]; and summarized in Table 1.
TABLE I

PhysicochemicAl Properties OF AGARWOOd LEAF ESSENTIAL OIL (ALEO) IN COMPARISON WITH OLIVE OIL AND AGARWOOD OIL (FROM RESIN INFILTRATED HEARTWOOD); NA: NOT AVAILABLE.

\begin{tabular}{|l|l|l|l|}
\hline $\begin{array}{l}\text { Physicochemical } \\
\text { property }\end{array}$ & Olive oil $^{[26]}$ & ALEO & $\begin{array}{l}\text { Agarwood } \\
\text { oil }\end{array}$ \\
\hline Colour & $\begin{array}{l}\text { Yellow to } \\
\text { green }\end{array}$ & Pale yellow & $\begin{array}{l}\text { Dark brown } \\
\text { to dark } \\
\text { yellow [24] }\end{array}$ \\
\hline Odour & NA & Sweet smell & $\begin{array}{l}\text { Sweet smell } \\
{[24]}\end{array}$ \\
\hline Refractive index & $1.468-1.471$ & 1.440 & $1.520[24]$ \\
\hline Specific gravity & $0.910-0.916$ & 0.886 & $0.952[24]$ \\
\hline $\begin{array}{l}\text { Saponification } \\
\text { value (mg } \\
\text { KOH/g) }\end{array}$ & $184-196$ & 131.88 & $195[24]$ \\
\hline $\begin{array}{l}\text { Acid value (mg } \\
\text { KOH/g) }\end{array}$ & $6.6(\mathrm{Max})$ & 2.80 & $8.6[30]$ \\
\hline $\begin{array}{l}\text { Iodine value } \\
\text { (gI } \mathbf{2} / \mathbf{1 0 0 g} \text { ) }\end{array}$ & $75-94$ & 105.07 & $186[24]$ \\
\hline
\end{tabular}

\section{B. GCMS analysis of ALEO Chemical Constituents}

Profiling of chemical constituents in plant species is an important step to complement investigation of medicinal effects of the plants. Chemical constituents identified from plants are potential source of drug templates [31]. The GCMS analysis revealed 19 compounds in ALEO. Isopropyl palmitate (hexadecanoic acid) which is a fatty acid was the most abundant component detected which accounted for $64.41 \%$ of overall oil content followed by 2-Propanol, 1,1'oxybis- $(8.4572 \%)$ and 1-Propanol, 2-(2-hydroxypropoxy)$(7.1958 \%)$. The relative contents expressed in the form of percentage of all compounds found in ALEO analyzed by GCMS are listed in Table 2 and categorized based on their functional groups. Meanwhile, Fig. 1 and Fig. 2 show an exemplary chromatogram of ALEO and the presence of azulene and guaiol with the peaks labeled (i) and (ii) respectively.

Previous study reported that hexadecanoic acid was found to be the major compound of Aquilaria sinensis leaf essential oil (48.86\%) [32] as well as the major compound (49.47\% of total essential oil) in healthy agarwood (Aquilaria sinensis (Lour.) Gilg) which contributes to its aromatic smell [33]. It was also reported that isopropyl myristate (tetradecanoic acid), isopropyl palmitate (hexadecanoic acid) and isopropyl stearate (octadecanoic acid) were present in the oils extracted from naturally infected and healthy Aquilaria agallocha Roxb. [34]. Moreover, fatty acids such as n-hexadecanoic acid, 9octadecenoic acid and (E), tetradecanoic acid are reported to posses antitumour activity [31]. Meanwhile, Dahham et al. who studied on the essential oil from the stem bark of Aquilaria crassna, stated that the presence of sesquiterpene compounds were reported to be the main active compounds in agarwood species and were believed to be the active principles of the plant [11]. Further, azulene $(0.6555 \%)$ and guaiol (0.2997\%); identified at minute 11.133 and 12.239 respectively were believed to be the biomarker of agarwood species with guaiol being one of the six compounds that could be indicated as the reference compound to determine the quality of agarwood [33], [34]. Overall, compounds 
identified in ALEO are consistent with agarwood biomarkers reported elsewhere suggesting the authenticity of the oil.

TABLE II

ClASSIFICATION OF THE IDENTIFIED CHEMICAL CONSTITUENTS OF ALEO BASED ON FUNCTIONAL GROUPS

\begin{tabular}{|c|c|c|}
\hline $\begin{array}{l}\text { Functional } \\
\text { group }\end{array}$ & Compound & Area $(\%)$ \\
\hline Monoterpene & Santolina epoxide & 0.477 \\
\hline Sesquiterpene & $\begin{array}{l}\text { Azulene, 1,2,3,5,6,7,8,8a- } \\
\text { octahydro-1,4-dimethyl-7-(1- } \\
\text { methylethenyl)-,[1S-(1. } \\
\text { alpha.,7.alpha.,8a.beta.)]- }\end{array}$ & 0.619 \\
\hline \multirow[t]{2}{*}{ Alkane } & Naphthalene, 2-butyldecahydro- & 0.471 \\
\hline & $\begin{array}{l}\text { trans, cis-2- } \\
\text { Ethylbicyclo[4.4.0]decane }\end{array}$ & 0.336 \\
\hline \multirow[t]{6}{*}{ Alcohols } & 2-Propanol, 1,1'-oxybis- & 8.457 \\
\hline & 1-Propanol, 2-(2-hydroxypropoxy)- & 5.406 \\
\hline & 2-Butanol, 3,3'-oxybis- & 1.453 \\
\hline & $\begin{array}{l}\text { 7.alpha.-Ethyl-8.beta.-hydroxy-2,6- } \\
\text { dimethylbicyclo[4.4.0]dec-1-ene }\end{array}$ & 0.940 \\
\hline & Guaiol (sesquiterpene alcohol) & 0.300 \\
\hline & $\begin{array}{l}\text { Patchouli alcohol (sesquiterpene } \\
\text { alcohol) }\end{array}$ & 2.356 \\
\hline Aldehydes & $\begin{array}{l}\text { 3-(4-Isopropylphenyl)-2- } \\
\text { methylpropionaldehyde }\end{array}$ & 0.656 \\
\hline \multirow[t]{7}{*}{ Esters } & Allyl phenoxyacetate & 1.670 \\
\hline & $\begin{array}{l}\text { Prop-2-ynyl (E)-2-methylbut-2- } \\
\text { enoate }\end{array}$ & 0.430 \\
\hline & Benzyl benzoate & 0.762 \\
\hline & $\begin{array}{l}\text { Isopropyl myristate (Tetradecanoic } \\
\text { acid) }\end{array}$ & 0.951 \\
\hline & i-Propyl 14-methyl-pentadecanoate & 1.038 \\
\hline & $\begin{array}{l}\text { Isopropyl palmitate (Hexadecanoic } \\
\text { acid) }\end{array}$ & 64.406 \\
\hline & $\begin{array}{l}\text { Isopropyl stearate (Octadecanoic } \\
\text { acid ) }\end{array}$ & 0.384 \\
\hline Ethers & Benzenamine, 3-ethoxy- & 0.643 \\
\hline
\end{tabular}

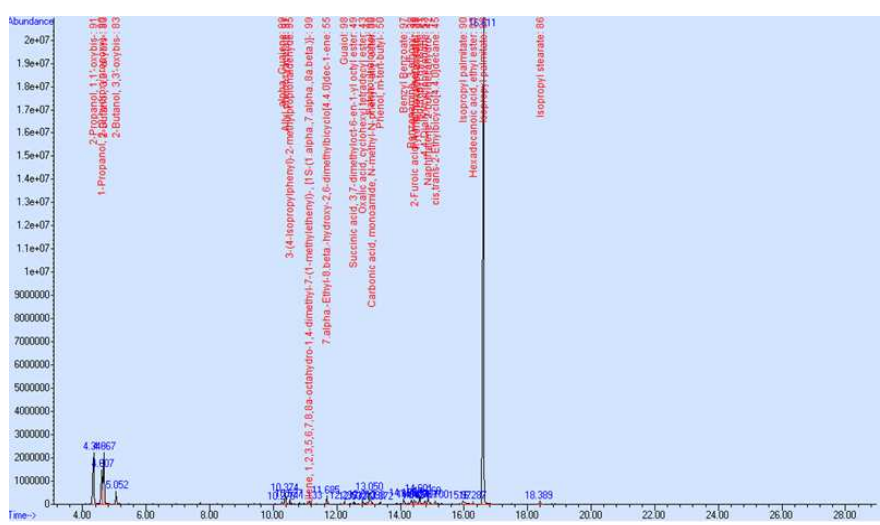

Fig. 1 Exemplary chromatogram of ALEO obtained using GCMS Agilent 7890A equipped with MSD quadrupole detector 5975 with capillary column of HP-5MS

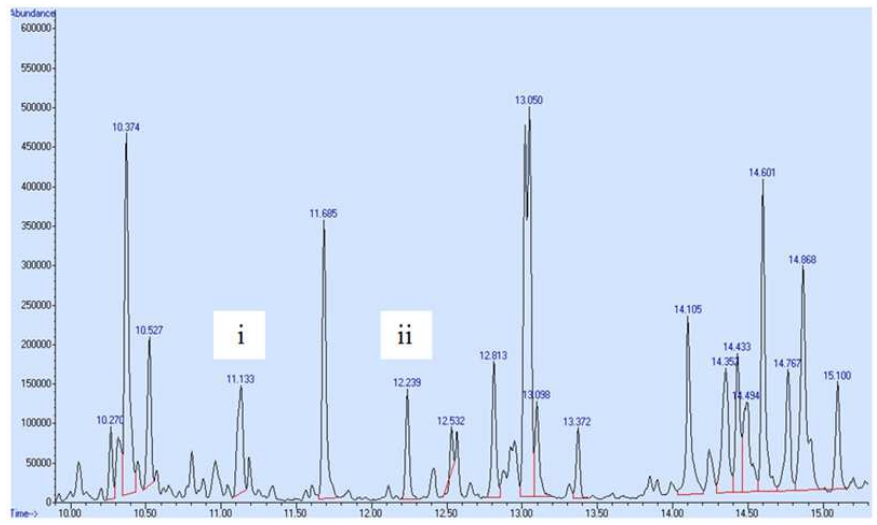

Fig. 2 The presence of the agarwood biomarkers labelled: (i) Azulene, 1,2,3,5,6,7,8,8a-octahydro-1,4-dimethyl-7-(1-methylethenyl)-,[1S-

(1.alpha.,7.alpha.,8a.beta.)]- at minute 11.133 and (ii) Guaiol at min 12.239

\section{In-vitro Anticancer Activity of ALEO}

The determination of inhibitory concentration $50 \%\left(\mathrm{IC}_{50}\right)$ value was performed by using WST- 8 assay. Fig. 3 shows the MCF-7 cells viability after being treated with ALEO for 36 hours. Based on the fitted curve as depicted in Fig. 3, it can be observed that $31 \%(\mathrm{v} / \mathrm{v})$ of ALEO caused $50 \%$ cell inhibition suggesting that ALEO has anticancer activity.

Dahham et al. (2016) revealed that the presence of monoterpenes, sesquiterpenes and aromatic compounds in essential oil from the stem bark of Aquilaria crassna, might have potent anticancer activities towards several types of cancers [12]. In the study, the essential oil exhibited significant antiproliferative activity against pancreatic cancer cells (MIA PaCa-2) which might be elucidated by the presence of phenolic and aromatic compounds such as azulene, $\quad \beta$-caryophyllene, 2-Naphtalenemethanol, benzenedicarboxylic acid, cyclodecene and octamethyl [12]. Sesquiterpenes have been reported to be responsible for antitumor activity including apoptotic activity against human promyelotic leukemia (HL-60) [35]. In another study, the presence of sesquiterpene compounds in myrrh essential oil was able to inhibit the anticancer effects against MCF-7 cells [10]. On the other hand, $\alpha$-humulene, caryophyllene oxide, tetradecanoic acid, n-hexadecanoic acid, isoledene and 9octadecenoic acid were reported to have antitumor properties [31].

To this end, the anticancer effects of ALEO against the MCF-7 breast cancer cells could be justified by the presence of sesquiterpene, aromatic compounds and fatty acids. 


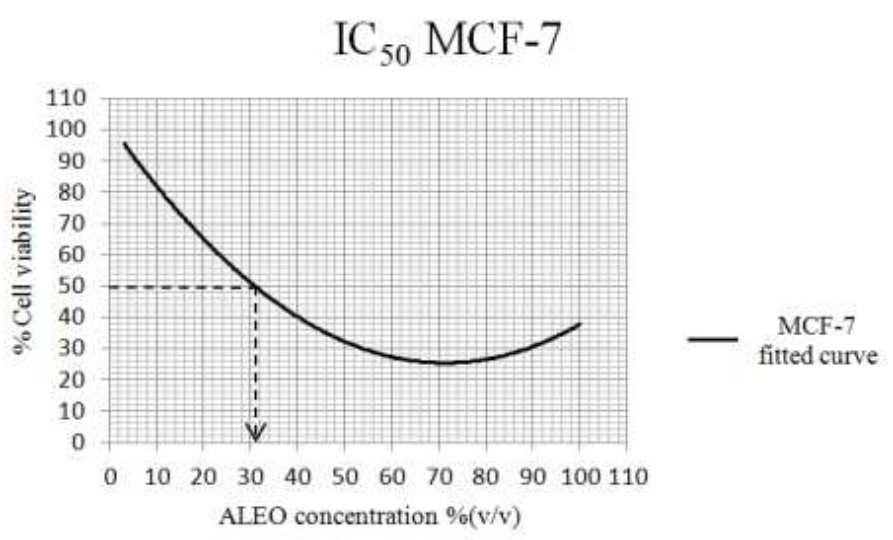

Fig. 3 Dose-response analysis of ALEO towards MCF-7 cells using WST-8 assay in 96-well format. Agarwood leaf essential oil (ALEO) concentration at $31 \%(\mathrm{v} / \mathrm{v})$ was able to inhibit $50 \%$ of cell viability after $36 \mathrm{~h}$ of treatment. Experiments were conducted in triplicates.

\section{CONCLUSIONS}

In conclusion, ALEO shows anticancer effects towards MCF-7 breast cancer cells. The anticancer effects shown could be explained by the presence of sesquiterpene, aromatic compounds and fatty acids. In terms of physicochemical properties, the values were found to be comparable and within the standard range with other essential oils. The presence of guaiol and azulene (biomarker) indicate that this commercial oil was extracted from agarwood plant species justifying the authenticity of the oil.

\section{ACKNOWLEDGMENT}

The authors would like to sincerely thank International Islamic University Malaysia for the Research Initiative Grant Scheme (RIGS17-145-0720) received in support for this present study.

\section{REFERENCES}

[1] L. A. Torre, F. Bray, R. L. Siegel, J. Ferlay, J. Lortet-Tieulent and A. Jemal, "Global cancer statistics, 2012," CA: a cancer journal for clinicians, vol. 65(2), pp. 87-108, Mar. 2015.

[2] J. Iqbal, B.A. Abbasi, T. Mahmood, S. Kanwal, B. Ali and A. T. Khalil, "Plant-derived anticancer agents: A green anticancer approach," Asian Pacific Journal of Tropical Biomedicine, Nov. 2017.

[3] (2018) WHO, World Health Organization website. [Online]. Available: $\quad$ http://www.who.int/en/news-room/factsheets/detail/cancer

[4] (2018) Cancer Research UK website. [Online]. Available: https://www.cancerresearchuk.org/about-cancer/breast-cancer/about

[5] K. J. Chavez, S. V. Garimella and S. Lipkowitz, "Triple negative breast cancer cell lines: one tool in the search for better treatment of triple negative breast cancer," Breast disease, vol. 32(1-2), p. 35, 2010.

[6] K. L. Maughan, M. A. Lutterbie and P. S. Ham, "Treatment of breast cancer," Chemotherapy, vol. 51, p. 53, 2010.

[7] S. Akter, M. T. Islam, M. Zulkefeli and S. I. Khan, "Agarwood production-a multidisciplinary field to be explored in Bangladesh," International Journal of Pharmaceutical and Life Sciences, vol. 2(1), pp. 22-32, 2013.

[8] H. H. Muhammad, M. F. Azlina, C. M. Hasfalina, Z. A. Zurina and J. Hishamuddin, "Optimization and kinetic study of gaharu oil extraction," World Academy of Science, Engineering and Technology, International Journal of Biological, Biomolecular, Agricultural, Food and Biotechnological Engineering, vol. 7(6), pp. 454-7, Jun 2013.

[9] Y. Z. H-Y. Hashim, P. G. Kerr, P. Abbas and H. M. Salleh, "Aquilaria spp. (agarwood) as source of health beneficial compounds: A review of traditional use, phytochemistry and pharmacology," Journal of Ethnopharmacology, vol. 189, pp. 331-60, Aug. 2016.

[10] Y. Z. H-Y. Hashim, A. Phirdaous and A. Azura, "Screening of anticancer activity from agarwood essential oil," Pharmacognosy research, vol. 6(3), p. 191, Jul. 2014.

[11] S.S.Dahham, Y. M. Tabana, M. A. Iqbal, M. B. Ahamed, M. O. Ezzat, A. S. Majid and A. M. Majid, "The anticancer, antioxidant and antimicrobial properties of the sesquiterpene $\beta$-caryophyllene from the essential oil of Aquilaria crassna,". Molecules, vol. 20(7), pp. 11808-29, Jun 2015

[12] S.S. Dahham, Y. M. Tabana, L. E. Hassan, M. B. Ahamed, A.S Majid and A. M. Majid, "In vitro antimetastatic activity of Agarwood (Aquilaria crassna) essential oils against pancreatic cancer cells," Alexandria Journal of Medicine, vol. 52(2), pp. 141-50, 2016.

[13] A. B. Caburian and M. O. Osi, "Characterization and evaluation of antimicrobial activity of the essential oil from the leaves of Piper betle L.," E-International Scientific Research Journal, vol. 2(1), pp. $2-13,2010$.

[14] (2018) Sucrose Conversion Table. [Online]. Available: https://www.greenwoodassociates.com/certs/Detailed\%20Brix\%20C hart.pdf.

[15] A. Author, "International commission for uniform methods of sugar analysis. Report of the proceedings of the ninth session, 1936," The Analyst, vol. 62(732), pp. 197-200, 1937.

[16] M. P. Paudyal, M. Rajbhandari, P. Basnet, S. Yahara and M. B. Gewali, "Quality assessment of the essential oils from Nardostachys jatamansi (D. Don) DC and Nardostachys chinensis batal obtained from Kathmandu valley market," Scientific World, vol. 10(10), pp. 13-6, Jul. 2012.

[17] I. M. Barkatullah, A. Rauf and K. Inyat-Ur-Rahman," Physicochemical characterization of essential and fixed oils of Skimmia laureola and Zanthoxylum armatum," Middle-East J. Med. Plants Res, vol. 1, pp. 51-8, 2012.

[18] AOAC (Association of Official Analytical Chemists), Official methods of analysis. Gaithersburg, MD, Washington, USA, 2000.

[19] Y. Z. Hashim, N. I. Ismail and P. Abbas, "Analysis of chemical compounds of agarwood oil from different species by gas chromatography mass spectrometry (GCMS)," IIUM Engineering Journal, vol. 15, p. 31, May, 2014.

[20] H. Tominaga, M. Ishiyama, F. Ohseto, K. Sasamoto, T. Hamamoto, K. Suzuki and M. Watanabe, "A water-soluble tetrazolium salt useful for colorimetric cell viability assay," Analytical Communications, vol. 36(2), pp. 47-50, 1999.

[21] S. Sahidin, S. Nakazibwe, M. Taher and A. K. Saxena, "SJA Ichwan Antiproliferative activity of Curcusone B from Jatropha curcas on human cancer cell lines," Aust. J. Basic Appl. Sci. Vol. 5, pp. 47-51, 2011.

[22] M. N. Boukhatem, F. M. Amine, A. Kameli, F. Saidi, K. Walid and S. B. Mohamed, "Quality assessment of the essential oil from Eucalyptus globulus Labill of Blida (Algeria) origin," International Letters of Chemistry, Physics and Astronomy, vol. 17(3), pp. 303-15, 2014.

[23] S. Clarke. Essential chemistry for aromatherapy. Elsevier Health Sciences, 2008

[24] H. Rahman, K. Vakati and M. C. Eswaraiah, "In-vivo and in-vitro anti-inflammatory activity of Aquilaria agallocha oil," International Journal of Basic Medical Sciences and Pharmacy, vol. 2(1), Jun 2012.

[25] D. Mishra, "Preparation of soap using different types of oils and exploring its properties" $\mathrm{PhD}$. thesis, Department of Chemical Enineering. National Institute of Technology, Rourkela, India, 2013.

[26] C. Alimentarius, Codex alimentarius standards for fats and oils from vegetable sources. Codex alimentarius standards for named vegetable oil. Codex Alimentarius Stan., vol. 210, 1999

[27] S. Dileesh, M. Adithya, A. Sankar and C. V. Peter, "Determination of saponification, acid and ester values; percentage of free fatty acids and glycerol in some selected edible oils: Calculation of concentration of lye needed to prepare soap from these oils," Research Scholar, pp. 2249-6696, 2013.

[28] C. Turek and F. C. Stintzing, "Stability of essential oils: a review," Comprehensive Reviews in Food Science and Food Safety. vol. 12(1), pp. 40-53, Jan. 2013.

[29] D. Tiran, Aromatherapy in Midwifery Practice. Singing Dragon, Jul 2016.

[30] H. Panda, Aromatic Plants Cultivation, Processing and Uses. Asia Pacific Business Press Inc., 2005. 
[31] M. Kilonzo, P. A. Ndakidemi and M. Chacha, "Mystroxylon aethiopicum chloroform root bark extracts phytochemical analysis using gas chromatography mass spectrometry," Journal of Pharmacognosy and Phytotherapy, vol. 9(4), pp. 44-50, Apr. 2017.

[32] L. Yufeng, Y. Xiuwei and L. Tonghua, "GC-MS Analysis of essential oil from the leaves of Aquilaria sinensis [J],"Modern Chinese Medicine vol. 8, p. 4, 2007.

[33] H. Chen, Y. Yang, J. Xue, J. Wei, Z. Zhang and H. Chen, "Comparison of compositions and antimicrobial activities of essential oils from chemically stimulated agarwood, wild agarwood and healthy Aquilaria sinensis (Lour.) Gilg trees," Molecules, vol. 16(6), pp. 4884-96, Jun. 2011.
[34] M. N. I. Bhuiyan, J. Begum and M. N. H. Bhuiyan, "Analysis of essential oil of eaglewood tree (Aquilaria agallocha Roxb.) by gas chromatography mass spectrometry," Bangladesh J Pharmacol., vol. 4, pp. 24-8, Jan. 2009.

[35] M. R. Serafini, D. M. Vergne, T. K. Rabelo, P. Menezes, R. Rocha, J. C. Moreira, F. Silva, P. B. Alves, H. Jesus, A. A. Araújo and D. P. Gelain, "Determination of chemical and physical properties of Hyptis pectinata essential oil and their redox active profile," Journal of Biotechnology and Pharmaceutical Research, vol. 3(1), pp. 1-9, 2012. 